\title{
Development of Economical Fertilizer-Based Media for Mass Culturing of Nannochloropsis oceanica
}

\author{
Jean Hee Bae and Sung Bum Hur* \\ Department of Marine Bio-materials and Aquaculture, Pukyong National University, Busan 608-737, Korea
}

\begin{abstract}
This study was conducted to develop economical agricultural fertilizer media for the mass culturing of Nannochloropsis oceanica. Specific growth rates of $N$. oceanica cultured with differing concentrations of commercial compounds, urea fertilizers, and trace elements $(\mathrm{Zn}, \mathrm{Cu}, \mathrm{Co}, \mathrm{Mo})$ were compared with the growth rate in $\mathrm{f} / 2$ medium. Among the various added trace elements, $\mathrm{CuSO}_{4} \cdot 5 \mathrm{H}_{2} \mathrm{O}$ was most effective for high growth of $N$. oceanica. The main nitrogen source in the agricultural fertilizers was ammonium, which was unsuitable for the growth of $N$. oceanica. Thus, the fertilizer at a lower concentration infused with $\mathrm{NaNO}_{3}$ as a nitrogen source was more effective than fertilizer at higher concentrations. In this study, the growth of $N$. oceanica cultured with an agricultural fertilizer medium composed of compound fertilizer $(41.7 \mathrm{mg} / \mathrm{L})$, urea fertilizer $(34.4 \mathrm{mg} / \mathrm{L}), \mathrm{NaNO}_{3}(150 \mathrm{mg} / \mathrm{L})$, and $\mathrm{CuSO} 4 \cdot 5 \mathrm{H}_{2} \mathrm{O}(0.0588 \mathrm{mg} / \mathrm{L})$ was similar to that of $N$. oceanica cultured in $\mathrm{f} / 2$ medium.
\end{abstract}

Key words: Agricultural fertilizer, Economical media, f/2 media, Nannochloropsis oceanica

\section{Introduction}

In the past, aquaculture was the main industry using microalgae commercially. Today, various businesses and industries, including those involved in supplementary health products, cosmetics, medicine, and bio-energy, are making extensive use of microalgae (Borowitzka and Borowitzka, 1988).

The advantages of using microalgae as commercial biomaterials include eco-friendly culture methods that allow for continuous reproduction and wide-ranging uses without pollutants. However, weaknesses include the sudden death of microalgae, which often leads to high costs and low productivity (Chisti, 2007).

The cost of microalgae used as live food in artificial seed production of shellfish is nearly $30 \%$ of the total cost of seed production (Borowitzka, 1997). However, if stable and economical microalgae production can be developed, microalgae will likely become one of the most important materials in bioindustry.

For mass production of microalgae, reagents used for in- door culture would be inappropriate because of their high cost. Instead, more economical resources, such as agricultural fertilizers, are frequently used (López-Ruíz et al., 1995; Valenzuela-Espinoza et al., 2002; Pacheco-Vega and SánchezSaavedra, 2009). Using agricultural fertilizers only, however, leads to the problem of lower cell growth rates than in common media such as f/2 (Guillard and Ryther, 1962).

Nannochloropsis oceanica is commonly used to culture rotifers for marine fishes (Cabrera et al., 2005; Kobayashi et al., 2005; Ferreira et al., 2009) and to create "green water" for nursery tanks (Cabrera and Hur, 2001) because they are nutritious and easy to mass-produce. Additionally, their high contents of vitamins (Brown et al., 1997), lipids (Patil et al., 2007; Seychelles et al., 2009), highly unsaturated fatty acids (Sukenik et al., 1993; Zittelli et al., 1999; Hu and Gao, 2003), protein (Volkman et al., 1993), and natural pigment (Lubián et al., 2000) distinguish $N$. oceanica as a prospective microalgal species to be further researched and developed for the marine
Open Access http://dx.doi.org/10.5657/FAS.2011.0317

This is an Open Access article distributed under the terms of the Creative Commons Attribution Non-Commercial License (http://creativecommons. org/licenses/by-nc/3.0/) which permits unrestricted non-commercial use, distribution, and reproduction in any medium, provided the original work is properly cited.
Received 20 April 2011; Revised 15 September 2011; Accepted 8 November 2011

*Corresponding Author

E-mail: hurs@pknu.ac.kr 
bio-industry (Becker, 1981; Harting et al., 1988; Cha et al., 2010). In this study, we sought to develop economical media that could effectively replace $\mathrm{f} / 2$ for the mass production of N. oceanica.

\section{Materials and Methods}

The agricultural fertilizers used in this study were as follows: urea fertilizer containing 46\% nitrogen and compound fertilizer (Nam-Hae Chemicals Inc., Yeosu, Korea) containing $22 \%$ nitrogen, $12 \%$ phosphorus, $17 \%$ potassium, and $3 \%$ magnesium. The amount of the fertilizers used in this study followed the Schreiber medium standard (Schreiber, 1927) that consists of $\mathrm{NaNO}_{3}(100 \mathrm{mg} / \mathrm{L})$ and $\mathrm{Na}_{2} \mathrm{HPO}_{4} \cdot 12 \mathrm{H}_{2} \mathrm{O}$ $(20 \mathrm{mg} / \mathrm{L})$. Because $1 \mathrm{~L}$ of filtered seawater with $166.7 \mathrm{mg}$ of compound fertilizer and $137.6 \mathrm{mg}$ of urea fertilizer equals the concentrations of nitrate and phosphate in Schreiber medium, this standard was set as 1.0 times the basic fertilizer medium. The fertilizers were ground, dissolved in warm water, and filtered immediately before use.

The N. oceanica (KMMCC-13) used in this study were obtained from the Korea Marine Microalgae Culture Center (KMMCC) at Pukyong National University, South Korea. To culture $N$. oceanica, the following steps were conducted. First, $100 \mathrm{~mL}$ of autoclaved fertilizer media and $10 \mathrm{~mL}$ of culture stock were put into a $250 \mathrm{~mL}$ Erlenmeyer flask. Standing cultures were then kept at $25^{\circ} \mathrm{C}$ under continuous lighting of 100 $\mu \mathrm{mol} \mathrm{m} \mathrm{m}^{-2} \mathrm{~s}^{-1}$ and $15 \mathrm{psu}$. The culture was conducted in triplicate. Cell density was assessed twice daily at the same times using a hemocytometer, and the daily specific growth rate (SGR) was measured by the Guillard method (1973): SGR = $3.322 \times \log \left(\mathrm{N}_{2} / \mathrm{N}_{1}\right) /\left(\mathrm{t}_{2}-\mathrm{t}_{1}\right)$, where $\mathrm{t}_{2}$ and $\mathrm{t}_{1}$ are culture days after inoculation, and $\mathrm{N}_{2}$ and $\mathrm{N}_{1}$ are the cell density at $\mathrm{t}_{2}$, and $\mathrm{t}_{1}$, respectively.

\section{Culturing N. oceanica with differing concentra- tions of fertilizers and addition of trace elements}

To find the optimal concentrations of fertilizers, cell growth was observed for 5 days in the following conditions: 1 . $f / 2$ medium as a control group, 2. fertilizer medium 1.0 times (166.7 mg/L of compound fertilizer and $137.6 \mathrm{mg} / \mathrm{L}$ of urea fertilizer), 3. fertilizer media 1.25 times $(208.4 \mathrm{mg} / \mathrm{L}$ of compound fertilizer and $172.0 \mathrm{mg} / \mathrm{L}$ of urea fertilizer), and 4 . fertilizer 1.5 times $(250.1 \mathrm{mg} / \mathrm{L}$ of compound fertilizer, 206.4 $\mathrm{mg} / \mathrm{L}$ of urea fertilizer).

For trace elements, those used in $\mathrm{f} / 2$ medium, such as $\mathrm{CoCl}_{2} \cdot 6 \mathrm{H}_{2} \mathrm{O}(0.110 \mathrm{mg} / \mathrm{L}), \mathrm{CuSO}_{4} \cdot 5 \mathrm{H}_{2} \mathrm{O}(0.0196 \mathrm{mg} / \mathrm{L})$, $\mathrm{ZnSO}_{4} \cdot 7 \mathrm{H}_{2} \mathrm{O}(0.044 \mathrm{mg} / \mathrm{L})$, and $\mathrm{Na}_{2} \mathrm{MoO}_{4} \cdot 2 \mathrm{H}_{2} \mathrm{O}(0.012$ $\mathrm{mg} / \mathrm{L})$, were added to the fertilizer medium at varying concentrations: $0.5,1.0,1.5$, and 2.0 times. The growth rates in these media were observed for 7 days and compared with the growth rate in $\mathrm{f} / 2$ medium.

\section{Effects of the addition of $\mathrm{NaNO}_{3}$}

The concentration of the previous fertilizer medium was reduced to $0.5,0.25$, and 0.17 times. Then, $\mathrm{CuSO}_{4} \cdot 5 \mathrm{H}_{2} \mathrm{O}$ $(0.0588 \mathrm{mg} / \mathrm{L})$ at three times the concentration in $\mathrm{f} / 2$ medium and $\mathrm{NaNO}_{3}(150 \mathrm{mg} / \mathrm{L})$ at the same concentration as in $\mathrm{f} / 2$ medium were added. This experiment involved eight groups, and daily growth in each of the following groups was measured for 7 days: 1) f/2 medium; 2) fertilizer medium 1.25 times; 3) fertilizer medium 0.5 times (compound fertilizer $83.4 \mathrm{mg} / \mathrm{L}+$ urea fertilizer $68.8 \mathrm{mg} / \mathrm{L}+\mathrm{NaNO}_{3}$ ); 4) group $3+$ $\mathrm{CuSO}_{4} \cdot 5 \mathrm{H}_{2} \mathrm{O} ; 5$ ) fertilizer medium 0.25 times (compound fertilizer $41.7 \mathrm{mg} / \mathrm{L}+$ urea fertilizer $34.4 \mathrm{mg} / \mathrm{L}+\mathrm{NaNO}_{3}$; 6) group $5+\mathrm{CuSO}_{4} \cdot 5 \mathrm{H}_{2} \mathrm{O} ; 7$ ) fertilizer medium 0.17 times (compound fertilizer $28.3 \mathrm{mg} / \mathrm{L}+$ urea fertilizer $23.4 \mathrm{mg} / \mathrm{L}+\mathrm{NaNO}_{3}$ ); and 8) group $7+\mathrm{CuSO}_{4} \cdot 5 \mathrm{H}_{2} \mathrm{O}$.

\section{Growth comparison with laboratory and indus- trial reagents}

To develop an economical fertilizer medium for the mass production of $N$. oceanica, the $\mathrm{NaNO}_{3}$ and $\mathrm{CuSO}_{4} \cdot 5 \mathrm{H}_{2} \mathrm{O}$ reagents were examined separately with laboratory reagents ( $\mathrm{NaNO}_{3}$, Samchun Pure Chemical Co., Ltd., Pyeongtaek, Korea; $\mathrm{CuSO}_{4} \cdot 5 \mathrm{H}_{2} \mathrm{O}$, Shimakyu's Pure Chemicals, Osaka, Japan) and industrial reagents $\left(\mathrm{NaNO}_{3}\right.$, Rifa Ind. Co. Ltd., Ludwigshafen, Germany; $\mathrm{CuSO}_{4} \cdot 5 \mathrm{H}_{2} \mathrm{O}$, Young Poong Inc., Seoul, Korea). The N. oceanica were cultured for 7 days and their growth was measured using the methods above.

\section{Statistics analyses}

Results were analyzed by one-way analysis of variance, and Duncan's multiple range test (Duncan, 1955) was used to detect significant differences at the level of $P<0.05$. SPSS ver. 17 (SPSS Inc., Chicago, IL, USA) was used for all analyses.

\section{Results}

\section{Growth according to concentration of fertilizers and addition of trace elements}

The growths of $N$. oceanica cultured in $\mathrm{f} / 2$ and agricultural fertilizer media for 5 days are shown in Fig. 1. The f/2 medium, as the control group, showed the significantly highest SGR of 0.3815 . In fertilizer medium 1.25 times, the growth rate of 0.3407 was significantly lower than that in $\mathrm{f} / 2$ medium. However, this growth rate was significantly higher than those of the other experimental groups $(P<0.05)$.

The results of the 7-day cultures of $N$. oceanica in fertilizer medium 1.25 times plus trace elements, $\mathrm{CoCl}_{2} \cdot 6 \mathrm{H}_{2} \mathrm{O}$, $\mathrm{CuSO}_{4} \cdot 5 \mathrm{H}_{2} \mathrm{O}, \mathrm{ZnSO}_{4} \cdot 7 \mathrm{H}_{2} \mathrm{O}$, and $\mathrm{Na}_{2} \mathrm{MoO}_{4} \cdot 2 \mathrm{H}_{2} \mathrm{O}$ at con- 


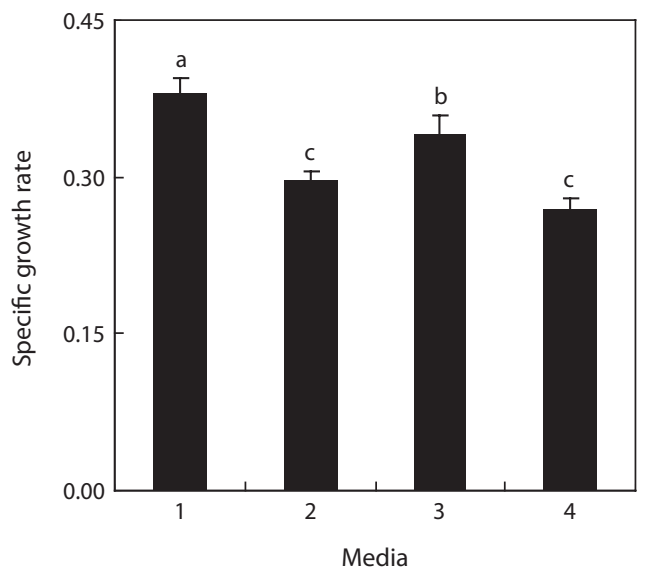

Fig. 1. Specific growth rate of Nannochloropsis oceanica cultured with agricultural fertilizer media $(1, \mathrm{f} / 2 ; 2$, compound fertilizer $166.7 \mathrm{mg} /$ $\mathrm{L}+$ urea fertilizer $137.6 \mathrm{mg} / \mathrm{L} ; 3$, compound fertilizer $208.4 \mathrm{mg} / \mathrm{L}+$ urea fertilizer $172.0 \mathrm{mg} / \mathrm{L} ; 4$, compound fertilizer $250.1 \mathrm{mg} / \mathrm{L}+$ urea fertilizer $206.4 \mathrm{mg} / \mathrm{L})$.

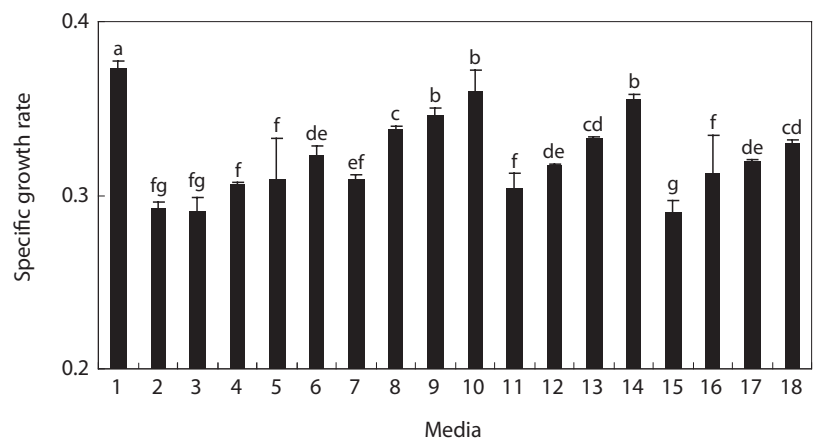

Fig. 2. Specific growth rate of Nannochloropsis oceanica cultured with agricultural fertilizer media added with different concentrations of trace elements $[1, \mathrm{f} / 2 ; 2$, compound fertilizer $208.4 \mathrm{mg} / \mathrm{L}+$ urea fertilizer 172.0 $\mathrm{mg} / \mathrm{L} ; 3,2+\mathrm{CoCl}_{2}(0.055 \mathrm{mg} / \mathrm{L}) ; 4,2+\mathrm{CoCl}_{2}(0.110 \mathrm{mg} / \mathrm{L}) ; 5,2+\mathrm{CoCl}_{2}$ $(0.165 \mathrm{mg} / \mathrm{L}) ; 6,2+\mathrm{CoCl}_{2}(0.220 \mathrm{mg} / \mathrm{L}) ; 7,2+\mathrm{CuSO}_{4} \cdot 5 \mathrm{H}_{2} \mathrm{O}(0.0098 \mathrm{mg} /$ $\mathrm{L}) ; 8,2+\mathrm{CuSO}_{4} \cdot 5 \mathrm{H}_{2} \mathrm{O}(0.0196 \mathrm{mg} / \mathrm{L}) ; 9,2+\mathrm{CuSO}_{4} \cdot 5 \mathrm{H}_{2} \mathrm{O}(0.0294 \mathrm{mg} / \mathrm{L}) ;$ $10,2+\mathrm{CuSO}_{4} \cdot 5 \mathrm{H}_{2} \mathrm{O}(0.0392 \mathrm{mg} / \mathrm{L}) ; 11,2+\mathrm{ZnSO}_{4} \cdot 7 \mathrm{H}_{2} \mathrm{O}(0.022 \mathrm{mg} / \mathrm{L}) ; 12$, $2+\mathrm{ZnSO}_{4} \cdot 7 \mathrm{H}_{2} \mathrm{O}(0.044 \mathrm{mg} / \mathrm{L}) ; 13,2+\mathrm{ZnSO}_{4} \cdot 7 \mathrm{H}_{2} \mathrm{O}(0.066 \mathrm{mg} / \mathrm{L}) ; 14,2+$ $\mathrm{ZnSO}_{4} \cdot 7 \mathrm{H}_{2} \mathrm{O}(0.088 \mathrm{mg} / \mathrm{L}) ; 15,2+\mathrm{Na}_{2} \mathrm{MoO}_{4} \cdot 2 \mathrm{H}_{2} \mathrm{O}(0.006 \mathrm{mg} / \mathrm{L}) ; 16,2+$ $\mathrm{Na}_{2} \mathrm{MoO}_{4} \cdot 2 \mathrm{H}_{2} \mathrm{O}(0.012 \mathrm{mg} / \mathrm{L}) ; 17,2+\mathrm{Na}_{2} \mathrm{MoO}_{4} \cdot 2 \mathrm{H}_{2} \mathrm{O}(0.018 \mathrm{mg} / \mathrm{L}) ; 18,2+$ $\left.\mathrm{Na}_{2} \mathrm{MoO}_{4} \cdot 2 \mathrm{H}_{2} \mathrm{O}(0.024 \mathrm{mg} / \mathrm{L})\right]$.

centrations of 0.5-2.0 times were as follows. Higher contents of trace elements produced higher growth rates of $N$. oceanica (Fig. 2). The fertilizer medium 1.25 times and the media infused with 0.5 times $\mathrm{CoCl}_{2} \cdot 6 \mathrm{H}_{2} \mathrm{O}(0.055 \mathrm{mg} / \mathrm{L})$ and $\mathrm{Na}_{2} \mathrm{MoO}_{4} \cdot 2 \mathrm{H}_{2} \mathrm{O}(0.006 \mathrm{mg} / \mathrm{L})$ showed the lowest growth rates in the range of $0.2903-0.2930$.

The growth rates of the experimental groups infused with $\mathrm{CuSO}_{4} \cdot 5 \mathrm{H}_{2} \mathrm{O}$ and $\mathrm{ZnSO}_{4} \cdot 7 \mathrm{H}_{2} \mathrm{O}$ were $0.3096-0.3598$ and $0.3042-0.3559$, respectively. These growth rates were relatively high compared with those for other media infused with $\mathrm{CoCl}_{2} \cdot 6 \mathrm{H}_{2} \mathrm{O}$ or $\mathrm{Na}_{2} \mathrm{MoO}_{4} \cdot 2 \mathrm{H}_{2} \mathrm{O}$, which showed rates of

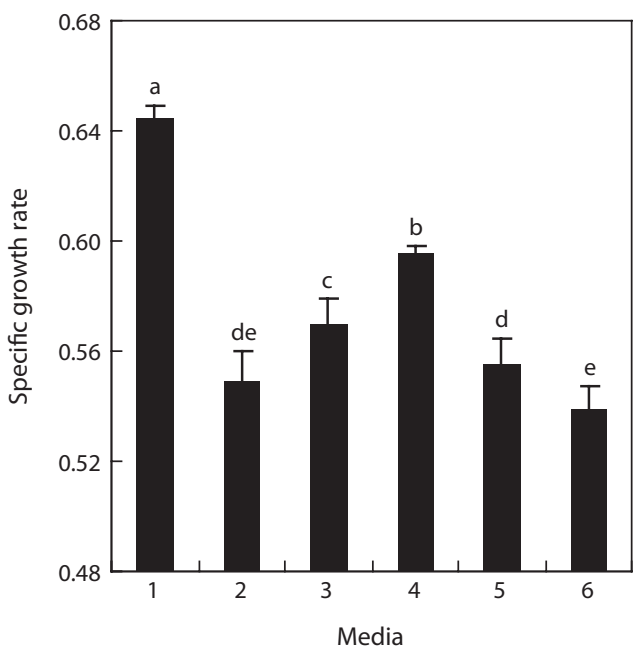

Fig. 3. Specific growth rate of Nannochloropsis oceanica cultured with agricultural fertilizer media added with different concentrations of $\mathrm{CuSO}_{4} .5 \mathrm{H}_{2} \mathrm{O}[1, \mathrm{f} / 2 ; 2$, compound fertilizer $208.4 \mathrm{mg} / \mathrm{L}+$ urea fertilizer $172.0 \mathrm{mg} / \mathrm{L} ; 3,2+\mathrm{CuSO}_{4} \cdot 5 \mathrm{H}_{2} \mathrm{O}(0.0392 \mathrm{mg} / \mathrm{L}) ; 4,2+\mathrm{CuSO}_{4} \cdot 5 \mathrm{H}_{2} \mathrm{O}(0.0588$ $\left.\mathrm{mg} / \mathrm{L}) ; 5,2+\mathrm{CuSO}_{4} \cdot 5 \mathrm{H}_{2} \mathrm{O}(0.0784 \mathrm{mg} / \mathrm{L}) ; 6,2+\mathrm{CuSO}_{4} \cdot 5 \mathrm{H}_{2} \mathrm{O}(0.098 \mathrm{mg} / \mathrm{L})\right]$.

\subsection{3-0.3231.}

In the experimental groups infused with either $1.5(0.0294$ $\mathrm{mg} / \mathrm{L})$ or 2 times $(0.0392 \mathrm{mg} / \mathrm{L}) \mathrm{CuSO}_{4} \cdot 5 \mathrm{H}_{2} \mathrm{O}$ and 2 times $\mathrm{ZnSO}_{4} \cdot 7 \mathrm{H}_{2} \mathrm{O}(0.088 \mathrm{mg} / \mathrm{L})$, the growth rates of $0.3457-$ 0.3598 were still significantly lower than the rate of 0.3726 for the control group in $\mathrm{f} / 2$ medium. However, the former groups showed higher growth rates than the rest of the experimental groups $(P<0.05)$.

To test the exact concentration of $\mathrm{CuSO}_{4} \cdot 5 \mathrm{H}_{2} \mathrm{O}$ for infusion, 2-, 3-, 4-, and 5-fold increased concentrations (0.0392-0.098 $\mathrm{mg} / \mathrm{L})$ of $\mathrm{CuSO}_{4} \cdot 5 \mathrm{H}_{2} \mathrm{O}$ were added to fertilizer medium 1.25 times and cultures were grown for 8 days. The results indicated the significantly highest growth rate of 0.6446 in the control $\mathrm{f} / 2$ group $(P<0.05)$ (Fig. 3). When three-fold $\mathrm{CuSO}_{4} \cdot 5 \mathrm{H}_{2} \mathrm{O}$ was added, the growth rate was 0.5955 . Although this growth rate was lower than that in $\mathrm{f} / 2$ medium, it was significantly higher than the other fertilizer media $(P<0.05)$. For more than three-fold $\mathrm{CuSO}_{4} \cdot 5 \mathrm{H}_{2} \mathrm{O}$ infusion, as the concentration of copper was increased, the growth rate decreased significantly $(P<0.05)$.

\section{Growth according to addition of $\mathrm{NaNO}_{3}$}

On the basis of the findings in this study, growth differences in $f / 2$ and fertilizer media seemed to be correlated with the high content of ammonia and low content of nitrate. With the infusion of $\mathrm{CuSO}_{4} \cdot 5 \mathrm{H}_{2} \mathrm{O}(0.0588 \mathrm{mg} / \mathrm{L})$ and $\mathrm{NaNO}_{3}(150$ $\mathrm{mg} / \mathrm{L})$, the amounts of fertilizers were reduced by 0.5 times (compound fertilizer, $83.4 \mathrm{mg} / \mathrm{L}$; urea fertilizer, $68.8 \mathrm{mg} / \mathrm{L}$ ), 0.25 times (compound fertilizer, $41.7 \mathrm{mg} / \mathrm{L}$; urea fertilizer, $34.4 \mathrm{mg} / \mathrm{L}$ ), and 0.17 times (compound fertilizer, $28.3 \mathrm{mg} / \mathrm{L}$; 


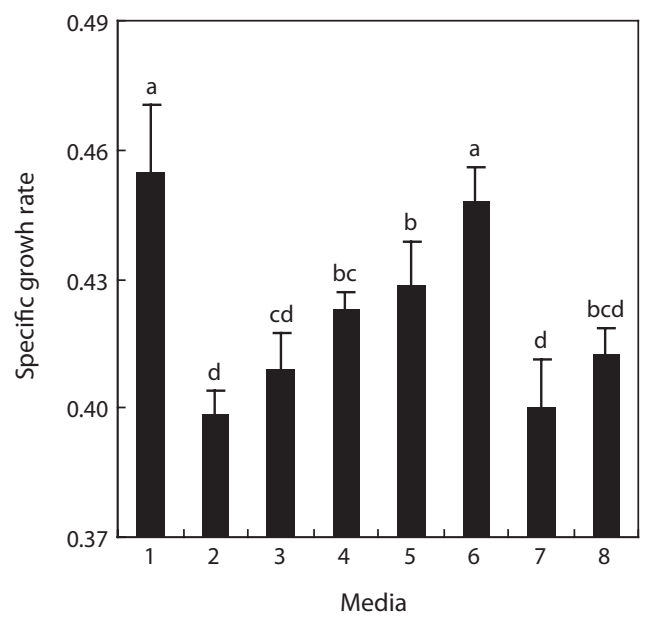

Fig. 4. Specific growth rate of Nannochloropsis oceanica cultured with low concentration of agricultural fertilizer media added with $\mathrm{NaNO}_{3}(150$ $\mathrm{mg} / \mathrm{L}$ ) and $\mathrm{CuSO}_{4}$ (0.0588 mg/L) [1, f/2; 2, compound fertilizer $208.4 \mathrm{mg} /$ $\mathrm{L}+$ urea fertilizer $172.0 \mathrm{mg} / \mathrm{L} ; 3$, compound fertilizer $83.4 \mathrm{mg} / \mathrm{L}+$ urea fertilizer $68.8 \mathrm{mg} / \mathrm{L}+\mathrm{NaNO}_{3} ; 4,3+\mathrm{CuSO}_{4} \cdot 5 \mathrm{H}_{2} \mathrm{O} ; 5$, compound fertilizer $41.7 \mathrm{mg} / \mathrm{L}+$ urea fertilizer $34.4 \mathrm{mg} / \mathrm{L}+\mathrm{NaNO}_{3} ; 6,5+\mathrm{CuSO}_{4} \cdot 5 \mathrm{H}_{2} \mathrm{O} ; 7$, compound fertilizer $28.3 \mathrm{mg} / \mathrm{L}+$ urea fertilizer $23.4 \mathrm{mg} / \mathrm{L}+\mathrm{NaNO}_{3} ; 8,7+$ $\mathrm{CuSO}_{4} \cdot 5 \mathrm{H}_{2} \mathrm{O}$.

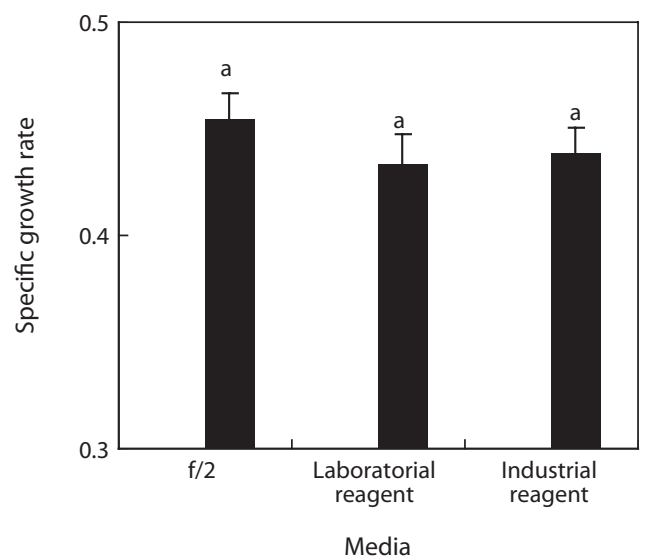

Fig. 5. Specific growth rate of Nannochloropsis oceanica cultured with agricultural fertilizer media (compound fertilizer $41.7 \mathrm{mg} / \mathrm{L}+$ urea fertilizer $34.4 \mathrm{mg} / \mathrm{L}$ ) added with laboratorial or industrial reagent of $\mathrm{NaNO}_{3}(150 \mathrm{mg} / \mathrm{L})$ and $\mathrm{CuSO}_{4} \cdot 5 \mathrm{H}_{2} \mathrm{O}(0.0588 \mathrm{mg} / \mathrm{L})$.

urea fertilizer, $23.4 \mathrm{mg} / \mathrm{L}$ ) the level in Schreiber culture medium. As a result (Fig. 4), the growth rate of 0.3985 in fertilizer medium 1.25 times was significantly the lowest rate $(P<$ $0.05)$. Fertilizer medium 0.25 times infused with $\mathrm{CuSO}_{4} \cdot 5 \mathrm{H}_{2} \mathrm{O}$ $(0.0588 \mathrm{mg} / \mathrm{L})$ and $\mathrm{NaNO}_{3}(150 \mathrm{mg} / \mathrm{L})$ showed a high growth rate of 0.4481 , about $96 \%$ of that in $\mathrm{f} / 2$ medium. In fact, this result was not significantly different from that in $\mathrm{f} / 2$ medium $(P<0.05)$.

\section{Growth rate comparison between laboratory and industrial reagents}

From the previously mentioned fertilizer media 0.25 times (compound fertilizer, $41.7 \mathrm{mg} / \mathrm{L}+$ urea fertilizer $34.4 \mathrm{mg} / \mathrm{L}$ ) infused with $\mathrm{CuSO}_{4} \cdot 5 \mathrm{H}_{2} \mathrm{O} 0.0588 \mathrm{mg} / \mathrm{L}$ and $\mathrm{NaNO}_{3} 150 \mathrm{mg} / \mathrm{L}$, $\mathrm{NaNO}_{3}$ and $\mathrm{CuSO}_{4} \cdot 5 \mathrm{H}_{2} \mathrm{O}$ were assessed separately with laboratory and industrial reagents. The growth rates of $N$. oceanica in fertilizer media with laboratory and industrial reagents were 0.4331 and 0.4383 , respectively (Fig. 5). These results indicated no significant difference compared with the growth rate $(0.4549)$ in $\mathrm{f} / 2$ medium $(P<0.05)$.

\section{Discussion}

Culture media for microalgae should be economical, allow for high growth rates, satisfy the needs of the microalgae, and be easy to prepare. F/2 medium, the most commonly used medium for small-scale indoor culture, is costly and difficult to set up for outdoor mass culture (Fabregas et al., 1985). Thus, agricultural fertilizers are commonly used as a replacement for f/2 culture medium (Fabregas et al., 1987; Bae, 2004; Pacheco-Vega and Sánchez-Saavedra, 2009). However, cell growth rates in such fertilizer-based media have not yet reached that in $\mathrm{f} / 2$ culture medium. The slower rate is attributable to the presence of nitrogen and phosphorus, major components in fertilizer cultures (Ukeles, 1980; González-Rodriguez and Maestrini, 1984; Bae, 2004). Lack of trace elements and vitamins necessary for the growth of microalgae are also reasons for lower growth rates (Stein, 1973).

Our aim was to develop media using economical and convenient agricultural fertilizers to replace $\mathrm{f} / 2$ medium for outdoor mass culture of $N$. oceanica, which has recently been in the commercial spotlight (Cha et al., 2010). Most common culture media for microalgae are based on Schreiber medium, containing $\mathrm{NaNO}_{3}(100 \mathrm{mg} / \mathrm{L})$ and $\mathrm{Na}_{2} \mathrm{HPO}_{4} \cdot 12 \mathrm{H}_{2} \mathrm{O}(20 \mathrm{mg} / \mathrm{L})$ (Schreiber, 1927). Thus, we tested for optimal concentrations of agricultural urea and compound fertilizers in relation to these nutrients.

From the second and third days after inoculation, the growth stage of the cells was in log phase in $\mathrm{f} / 2$ media. On the other hand, fertilizer media showed a longer lasting lag phase, and the lower level of the ultimate highest cell density was problematic. The following factors are believed to have caused such results: urea fertilizer, consisting of $46 \%$ nitrogen, and compound fertilizer consisting of $22 \%$ nitrogen, $12 \%$ phosphorus, $17 \%$ potassium, and $3 \%$ magnesium. Other causes may have been the lack of essential trace elements for the growth of $N$. oceanica and a nitrogen source consisting mostly of ammonia.

After adding the four trace elements $(\mathrm{Co}, \mathrm{Cu}, \mathrm{Zn}, \mathrm{Mo})$ used in $\mathrm{f} / 2$ medium to each fertilizer medium, growth rates of $N$. oceanica were observed. When $\mathrm{CuSO}_{4} \cdot 5 \mathrm{H}_{2} \mathrm{O}(0.0588 \mathrm{mg} / \mathrm{L})$ three times the concentration in $\mathrm{f} / 2$ medium was added, the $N$. oceanica growth rate was $80 \%$ of that in $\mathrm{f} / 2$ medium. $\mathrm{Cu}$ is essential for the growth of microalgae especially for pho- 
tosynthesis and enzymatic reactions (Andrade et al., 2004). However, Okauchi et al. (2008) claimed that zinc and cobalt had greater influence than copper on the growth of $\mathrm{N}$. oculata (see Guillard, 1973). In this study, however, copper was the most effective factor in the growth of Nannochloropsis. In Bae's (2004) study, the concentration of $\mathrm{Cu}$ added to $\mathrm{f} / 2$ medium was increased 2 to 80 times, and the growth rate of $N$. oceanica began to decrease above 5 times concentration $\left(\mathrm{CuSO}_{4} \cdot 5 \mathrm{H}_{2} \mathrm{O} 0.0196 \mathrm{mg} / \mathrm{L}\right)$.

González-Rodriguez and Maestrini (1984) used 12 kinds of fertilizers for 16 microalgal species with Conway medium as a control (Walne, 1966). The result of their research, which was similar to our result, showed extremely low growth rates of Nannochloris oculata, Isochrysis galbana, Chlamydomonas palla, and Chaetoceros sp. However, for Phaeodactylum tricornutum, Skeletonema costatum, Tetraselmis striata, and Thalassiosira pseudonana, growth rates were similar to or higher than that in Conway medium, the control group. Such differences in growth rates could be due to the nitrogen source, requiring differing media for each kind of microalgae.

Bae (2004) cultured N. oceanica with agricultural fertilizer for 16 days and then analyzed the water. The results showed that the concentration of $\mathrm{NH}_{4}-\mathrm{N}(10.0 \mathrm{ppm})$ in agricultural fertilizer was approximately 154 times higher than that in $\mathrm{f} / 2$ culture medium $(0.065 \mathrm{ppm})$; in addition, the concentration of $\mathrm{PO}_{4}-\mathrm{P}$ was nine times higher. These results imply that the growth of microalgae depends on their sensitivity to the ammonium concentration (1 mg atom N/L) (Kaplan et al., 1986). If the concentration is higher than $0.5 \mathrm{mg}$ atom $\mathrm{N} / \mathrm{L}$, the growth of microalgae exposed to high intensities of light and $\mathrm{pH}$ is likely to decrease (Admiraal, 1977; Kalpan et al., 1986).

In this study, the growth of microalgae in the fertilizer media was slower than that in $\mathrm{f} / 2$ medium in the early stages of the experiment. The low level of the highest cell density was also believed to be due to the high ammonium content.

Thus, to reduce the concentration of ammonia in the fertilizer media, the amounts of fertilizers were reduced to $25 \%$ of Schreiber's nitrate and phosphate concentrations. The growth of $N$. oceanica in fertilizer media infused with $\mathrm{NaNO}_{3}(150$ $\mathrm{mg} / \mathrm{L})$ and $\mathrm{CuSO}_{4} \cdot 5 \mathrm{H}_{2} \mathrm{O}(0.0588 \mathrm{mg} / \mathrm{L})$ and that in $\mathrm{f} / 2 \mathrm{me}-$ dium showed no significant difference $(P<0.05)$. Moreover, in the case of using $\mathrm{NaNO}_{3}$ and $\mathrm{CuSO}_{4} \cdot 5 \mathrm{H}_{2} \mathrm{O}$, which are less costly than industrial fertilizers, the growth rate of $N$. oceani$c a$ showed no significant difference compared with that in $\mathrm{f} / 2$ medium $(P<0.05)$.

In conclusion, for 1 ton of filtered seawater, an optimal medium for the mass culturing of $N$. oceanica can be achieved with the following materials: urea fertilizer containing $22 \%$ nitrogen (34.4 g), compound fertilizer containing 22\% nitrogen, $12 \%$ phosphorus, $17 \%$ potassium, and 3\% magnesium (41.7 g), and industrial reagent grade $\mathrm{NaNO}_{3}(150 \mathrm{~g})$ and $\mathrm{CuSO}_{4} .5 \mathrm{H}_{2} \mathrm{O}(0.0588 \mathrm{~g})$.

\section{Acknowledgments}

This work was supported by the National Research Foundation of Korea(NRF) grant funded by the Korea government (MEST) (No. 2010-0027713) and a part of the project titled "Marine Biotechnology Program" funded by the Ministry of Land, Transport and Maritime Affairs, Korea.

\section{References}

Admiraal W. 1977. Tolerance of estuarine benthic diatoms to high concentrations of ammonia, nitrite ion, nitrate ion and orthophosphate. Mar Biol 43, 307-315.

Andrade LR, Farina M and Amado GM. 2004. Effects of copper on Enteromorpha flexuosa (Chlorophyta) in vitro. Ecotoxicol Environ Saf 58, 117-125.

Bae JH. 2004. Selection of seasonal optimum Chlorella and Nannochloris species and development of media for mass culture. Ph.D. Dissertation, Pukyong National University, Busan, KR.

Becker EW. 1981. Algae mass cultivation: production and utilization. Process Biochem 16, 10-14.

Borowitzka MA. 1997. Microalgae for aquaculture: opportunities and constraints. J Appl Phycol 9, 393-401.

Borowitzka MA and Borowitzka LJ. 1988. Micro-algal Biotechnology. Cambridge University Press, New York, US.

Brown MR, Jeffrey SW, Volkman JK and Dunstan GA. 1997. Nutritional properties of microalgae for mariculture. Aquaculture 151, 315-331.

Cabrera T and Hur SB. 2001. The nutritional value of live foods on the larval growth and survival of Japanese flounder, Paralichthys olivaceus. J Appl Aquc 11, 35-53.

Cabrera T, Bae JH, Bai SC and Hur SB. 2005. Effects of microalgae and salinity on the growth three types of the rotifer Brachionus plicatilis. J Fish Sci Technol 8, 70-75.

Cha SH, Kim MJ, Yang HY, Jin CB, Jeon YJ, Oda T and Kim D. 2010. ACE, $\alpha$-glucosidase and cancer cell growth inhibitory activities of extracts and fractions from marine microalgae, Nannochloropsis oculata. Korean J Fish Aquat Sci 43, 437-444.

Chisti Y. 2007. Biodiesel from microalgae. Biotechnol Adv 25, 294306.

Duncan DB. 1955. Multiple range and multiple $F$ tests. Biometrics 11, $1-42$.

Fabregas J, Herrero C, Cabezas B and Abalde J. 1985. Mass culture and biochemical variability of the marine microalgae Tetraselmis suecica Kylin (Butch) with high nutrient concentrations. Aquaculture 49, 231-244.

Fabregas J, Toribio L, Abalde J, Cabezas B and Herrero C. 1987. Approach to biomass production of the marine microalga Tetraselmis suecica (Kylin) butch using common garden fertilizer and soil extract as cheap nutrient supply in batch cultures. Aquac Eng 6, 141-150.

Ferreira M, Coutinho P, Seixas P, Fábregas J and Otero A. 2009. Enriching rotifers with "premium" microalgae. Nannochloropsis ga- 
ditana. Mar Biotechnol 11, 585-595.

González-Rodriguez E and Maestrini SY. 1984. The use of some agricultural fertilizers for the mass production of marine algae. Aquaculture 36, 245-256.

Guillard RRL 1973. Division rates. In: Handbook of Phycological Methods. Culture Method and Growth Measurement. Stein JR, ed. Cambridge University Press, Cambridge, GB, pp. 289-311.

Guillard RRL and Ryther JH. 1962. Studies of marine plankton diatoms.

I. Cyclotella nana Hustedt, and Detonula confervacea (Cleve) Gran. Can J Microbiol 8, 229-239.

Harting P, Grobbelaar JU, Soeder CJ and Groeneweg J. 1988. On the mass culture of microalgae: a real density as an important factor for achieving maximal productivity. Biomass 15, 211-221.

$\mathrm{Hu} \mathrm{H}$ and Gao K. 2003. Optimization of growth and fatty acid composition of a unicellular marine picoplankton, Nannochloropsis sp., with enriched carbon sources. Biotechnol Lett 25, 421-425.

Kalpan D, Richmond AE, Dubinsky Z and Aaronson S. 1986. Algal nutrition. In: Handbook of Microalgal Mass Culture. Richmond A, ed. CRC Press, Boca Raton, FL, US, pp. 147-197.

Kobayashi T, Nagase T, Kurano N and Hino A. 2005. Fatty acid composition of the L-type rotifer Brachionus plicatilis produced by a continuous culture system under the provision of high density Nannochloropsis. Nippon Suisan Gakkaishi 71, 328-334.

López-Ruíz JL, García-García RG, Soledad M and Almeda F. 1995. Marine microalgae culture: Chaetoceros gracilis with zeolitic product Zestec-56 and a commercial fertilizer as a nutrient. Aqauc Eng 14, 367-372.

Lubián LM, Montero O, Moreno-Garrido I, Huertas IE, Sobrino C, González-del Valle M and Parés G. 2000. Nannochloropsis (Eustigmatophyceae) as source of commercially valuable pigments. J Appl Phycol 12, 249-255.

Okauchi M, Yamada T and Ozaki A. 2008. Optimum media for outdoor large-scale and indoor small-scale batch style culture of Nannochloropsis oculata. Aquac Sci 56, 147-155.

Pacheco-Vega JM and Sánchez-Saavedra MDP. 2009. The biochemical composition of Chaetoceros muelleri (Lemmermann Grown) with an agricultural fertilizer. J World Aquac Soc 40, 556-560.

Patil V, Källqvist T, Olsen E, Vogt G and Gislerød HR. 2007. Fatty acid composition of 12 microalgae for possible use in aquaculture feed. Aquacult Int 15, 1-9.

Schreiber E. 1927. Die Reinkultir von marinem phytoplankton und deren bedeutung für die erforschung der produktionsfähigkeit des meerwassers. Wiss Meersuntersuch NF 16, 1-34.

Seychelles LH, Audet C, Tremblay R, Fournier R and Pernet F. 2009. Essential fatty acid enrichment of cultured rotifers (Brachionus plicatilis, Müller) using frozen-concentrated microalgae. Aqauc Nutr 15, 431-439.

Stein JR. 1973. Handbook of Phycological Methods: Culture Methods and Growth Measurement. Cambridge University Press, Cambridge, GB.

Sukenik A, Zmora O and Carmeli Y. 1993. Biochemical quality of marine unicellular algae with special emphasis on lipid composition. II. Nannochloropsis sp. Aquaculture 117, 313-326.

Ukeles R. 1980. American experience in the mass culture of microalgae for feeding larvae of the American oyster, Crassostrea virginica. In: Algae Biomass: Production and Use. Shelef G and Soeder CJ, eds. Elsevier/North Holland Biomedical Press, Amsterdam, NL, pp. 287-306.

Valenzuela-Espinoza E, Millán-Nûnez R and Núnez-Cebrero F. 2002. Protein, carbohydrate, lipid and chlorophyll a content in Isochrysis aff. galbana (clone T-Iso) cultured with a low cost alternative to the f/2 medium. Aquac Eng 25, 207-216.

Volkman JK, Brown MR, Dunstan GA and Jeffrey SW. 1993. The biochemical composition of marine microalgal from the class Eustigmatophyceae. J Phycol 29, 69-78.

Walne PR. 1966. Experiments in the large-scale culture of the larvae of Ostrea edulis L. Fish Invest London Ser II 25, 1-53.

Zittelli GC, Lavista F, Bastianini A, Rodolfi L, Vincenzini M and Tredici MR. 1999. Production of eicosapentaenoic acid by Nannochloropsis sp. cultures in outdoor tubular photobioreactors. J Biotechnol 70, 299-312. 